\title{
THE IMPORTANCE AND THE ROLE OF TOURISM IN THE ECONOMIC AND SOCIAL LIFE OF ALBA COUNTY
}

\author{
Claudia Olimpia Moisă ${ }^{1}$
}

\begin{abstract}
With an extremely varied natural landscape and an attractive and complex anthropic tourism potential, Alba County is unfortunately below the national average in terms of heritage tourism leverage but, through the stakeholders involvement, with big prospects of development in terms of tourism.

The objective of this paper is to highlight the role played by the tourism activity in the economy of Alba County. For this purpose, a thorough analysis was done regarding what tourism means and which are the factors that influence it, it was stressed the role and both the economic and social importance at the county Alba and were identified the main opportunities for its development.
\end{abstract}

Keywords: tourism, Alba County, the role and importance of tourism

JEL codes: $M 31, L 83$

\section{Introduction}

Given the fact that Alba County is little known in terms of tourism among specialists and even tourists, we considered relevant an analysis of tourism activity at county level.

In this respect, they were briefly presented the theoretical framework of the phenomenon, then identified the main tourism resources available in Alba and tourist destinations preferred by tourists, it was outlined the role and the importance held by the tourism sector in the economy of Alba County, and last but not least, there have been identified directions of action for its development and promotion. In order to determine the economic and social role that tourism plays it were analyzed specific indicators of the touristic supply and demand.

Starting from the definition of tourism, as a pleasant way of leisure - provided that people who practice this type of activity - tourists - to travel from their place of residence for at least 24 hours and up to one year, for reasons such as relaxation, leisure and recreation, visiting relatives or friends, religious, professional, sporting, scientific, etc., without carring out any paid work in thosse places, it can be said that Alba county can meet these tourism needs.

Associated to these reasons for travel, the forms of tourism in Alba County are: leisure tourism, movement tourism ${ }^{2}$ which includes transit tourism and the traffic for sightseeing, mountaineering (sports and hiking), rural tourism, business tourism, religious tourism, hunting and fishing, etc.

Viewed from a macroeconomic perspective, the tourism is an economic and social activity in the tertiary sector of the national economy, which is influenced by other branches of the economy and also has a positive impact on other fields.

In establishing the importance of tourism activity, a dominant role is played by the factors that influence it both positively and negatively. Among these it may be mentioned as the most

\footnotetext{
1 "1 Decembrie 1918" University of Alba Iulia, Faculty of Science, Gabriel Bethlen Street, no.5, Alba Iulia, claudiapatrut@yahoo.com

${ }^{2}$ Borza A. (coord.), Tourist capitalization of tangible and intangible heritage of Alba County, ALTIP Publishing House, Alba Iulia, 2014.
} 
important: the economic factors, technical factors, social factors, demographic factors, organizational and political factors, natural factors, tourism demand and supply factors.

The economic benefits of the tourism industry are plenty. The tourism industry generates a significant number of jobs and investments in this area have a relatively short payback period. At the same time, the local economy as a whole benefits from the tourism development, as the touristic locations tend to have a more developed urban infrastructure and services.

The tourists creates additional demand for services and consumer goods, thereby stimulating the economy's tertiary sector (services, commerce, cottage industries etc.). The transport sector and real estate sector are other two important branches which earn a lot through tourism development.

Consideration should be given also to the indirect benefits achieved by the increasing visibility and interest for those regions which recorded a large influx of tourists ${ }^{3}$.

\section{Literature review}

Previous research regarding the role and importance of tourism in the national economy, are centered on highlighting the contribution of tourism to the economic and social development (Minciu R., 2004) or growth (Snak O., P. Baron, N. Neacsu , 2001).

As an example, R. Minciu believes that "the tourism action manifests itself on a variety of plans, as from stimulating the economic growth to improve the social structure, from better use of resources to economic and social progress...". ${ }^{4}$ Likewise, Cosmescu I. presents the tourism as a phenomenon with a multifunctional approach, as thet human experience, social behavior, as a geographical phenomenon, as a business and source of income, as well as industry. ${ }^{5}$

Other authors highlight the importance and role of tourism in the dimensions that it has at a macroeconomic level, considering it "a sector with a complex profile, a true aggregate with multiple services and activities, with implications in all economic and social sectors...". For the whole national economy, the tourism acts as a stimulating element of the global economic system. ${ }^{7}$ Also, the study of the economic and social impact of tourism is the subject of several other papers. (Minciu R., 2004; Neagu V., 2000; Cristureanu C., 2006). Recent studies prove once again that "tourism represents one of the most important factors influencing economic growth and development of contemporary societies". .8

The pioneer research in Alba County tourism phenomenon is Al. Borza (biological son of the same name, originating from Sebes Valley who created the first national park in Romania Retezat Park and Botanical Garden in Cluj Napoca ${ }^{9}$ ), who along his whole professional career was in charge of tourism issues.

Thus, in the paper - Tourist capitalization of tangible and intangible heritage of Alba County - tourism resources from Alba County are presented ,together with the forms of tourism in the county, the aspects regarding the touristic offer and the tourism movement, along with proposals for the tourism recovery of $1976^{10}$, in other words it is the most comprehensive study that highlights the position held by the tourism activity in county's economy in the 70's.

\footnotetext{
${ }^{3}$ ADR Center, Issues regarding tourism development in the Central Region, 2011.

${ }^{4}$ Minciu R.,The Tourism economy, the revised third edition, Uranus Publishing House, Bucharest, 2004.

${ }^{5}$ Cosmescu I., The Tourism - contemporary complex phenomenon, Economic Publishing House, Bucharest, 1998.

${ }^{6}$ Ioncică M., G. Stănciulescu, Tourism and services economy - a priority in a new economy, Uranus Publishing House, Bucharest, 2005.

${ }^{7}$ Bran F., Marin D., Simon T., The Economy of tourism and of the surounding environment, Economic Publishing House, Bucharest, 1998.

${ }^{8}$ Aziri B., Nedelea Al., Business strategies in tourism, Ecoforum Revue, Volume 2, Issue 1 (2), 2013.

${ }^{9}$ Borza Al., My roads through tourism, bio-bibliographical landmarks, ASE, Bucharest, 2011.

${ }^{10}$ Borza Al. (eds.), Tourist capitalization of tangible and intangible heritage of Alba County (1976), Publisher ALTIP, Alba Iulia, 2014.
} 
Of course there are other specialists who were bent on studying tourist activity in the county, specifically on the importance it holds in all economic sectors ${ }^{11},{ }^{12}$ but their results are not so recent.

\section{The research methodology}

To characterize the tourism phenomenon in Alba County, were taken the following actions:

- it was studied the specific literature for identifing the studies or works that refer to the tourism coordinates in Alba County,

- there were investigated the existing statistical data on tourist flows and infrastructure and also were inventoried the main resources and tourist destinations in the county

- direct research has been undertaken among the tourist market players and also between the stakeholders interested in the development of this sector.

\section{Main resources and tourist destinations of Alba County}

The Alba County, like any tourist destination, has a number of distinctive features, namely natural and anthropogenic resources, tourism infrastructure elements, human resources, etc.

Alba County is one of the counties that has a remarkable tourist potential, with some unique features (see Fig. no. 1).

Among the most important natural tourist resources are included:

- varied geographical landscape represented by a part of the Apuseni Mountains (specifically southern areas of Bihor Mountains and Great Mountain Massif and Trascău) and Şureanu Mountains which reach a maximum altitude of 2,130 county-level m in Pătru's Peak;

- an important number of phenomena and natural monuments representative at a national and european level ${ }^{13}$ ( Glacier Scărişoara cave, Vârtop cave both part of the Apuseni Natural Park, the massive basaltic Detunata, Trascău Mountains karst area - Râmeţ Gorge, Vălişoarei Gorge- , flora reserves of the massive Scărişoara-Belioara from Tecşeşti and Negrileasa);

- the specific mountainous climate in most of the county with moderate temperatures and unpolluted air, cool summers and snowy winters that keep 4-5 months / year;

- the hydrography represented by mountain lakes with very varied origins - Iezerul Şureanu (glacial) located in the Şureanu mountains at $1750 \mathrm{~m}$ altitude ${ }^{14}$, Iezerul Ighiel (karst) which is the most typical karst sinkholes lake in our country, Bottomless Lake Taul (natural dam) which has an area of 1.5 ha and a water volume of $22,623 \mathrm{~m} 3$ is considered among the largest natural reservoirs from the hilly region, the Mures river basin (140 km Alba County) with its tributaries Târnava, Arieş, Ampoi, Sebes and Cugir;

- the extremely rich and appealing flora and fauna, represented by species that survived the glacial times (albumela, silver or greasy sheet) thermophilic species of Mediterranean origin (fern Mediterranean $^{15}$ within the protected area Râpa Rosie), Illyrian or balcano- moesiacă ${ }^{16}$, edelweiss, rare species of bats, tree frog, green lizard and wall lizard (species that are of community interest and require strict protection ${ }^{17}$ ), golden eagle in Trascău Râmeț Gorges or the ice duck, the mountain cock: $;^{18}$

\footnotetext{
${ }^{11}$ Stremtan F. (eds.), New economic paths in the Apuseni Mountains, Risoprint Publishing House, Cluj Napoca, 2006.

${ }^{12}$ Luduşan N., Hanciu I., Hanciu M., M. Munteanu, The Geography of Alba County, Publisher Aeternitas, Alba Iulia, 2003.

${ }^{13}$ Borza Al. (eds.), Tourist capitalization of tangible and intangible heritage of Alba County (1976), Publisher ALTIP, Alba Iulia, 2014 p.19

${ }^{14}$ Luduşan N., Hanciu I., Hanciu M., M. Munteanu, The Geography of Alba county, Publisher Aeternitas, Alba Iulia, 2003, p. 75.

${ }^{15} \mathrm{https} / / /$ ro.wikipedia.org/wiki/Rapa_Rosie (accessed on 04.06.2015)

${ }^{16}$ Luduşan N., Hanciu I., M. Hanciu, Munteanu M., op.cit., P. 78

${ }^{17} \mathrm{https} / / /$ asociatiabiounivers.wordpress.com/proiecte-in-derulare/biodiversitatea-comoara-ascunsa-in-cheilevalisoarei/comoara-din-cheile-valisoarei-340-de-specii-identificate/ (accessed on 04.22.2015)

${ }^{18}$ About the famousroosters "fights" of Tărtărău şi Smida Mare wrote by Sadoveanu and Ionel Pop
} 
- an impressive list of natural reservations ${ }^{19}$, among which the most important are: Apuseni Natural Park (76 064 ha, of which 21,239 ha in Alba County), Limestone from Ampoiţa, Întregalde Gorge, Gorge Monastery (150 ha), Râmeţ Gorges (40 ha) Vălişoara gorge, ," Detunata Goala" (24 ha), "Detunata Flocoasa"," Iezerul Ighiel" (20 ha)," Iezerul Surean" (20 ha), "Izbucul Mătişeşti" (protected species), "Laricetul" from Vidolm (44.2 ha), "Masa Jidovului" (protected species), The Heat Egg (natural monument from Sebes Valley), Sloboda Forest (20 ha), Daffodil Meadow Negrileasa (Bucium), the Tecşeşti Daffodil Meadows, Stone Glade (Ighiel), Stone Cetii (75 ha), Bobi Creek (type paleontological Gârbova de Sus), Huda's Papara, Coiba Mare Cave, Scarisoara Glacier Cave, Dragons Gate Cave, Glacier Vârtop Cave, Râpa Roşie (geological and botanical type, Sebeş), "Șesul Craiului - Scărița - Belioara" (geological and botanical 47.7 ha), "Vânătările Ponorului”(Ponor Sălciua).



Fig. no. 1 Alba County tourism resources

Source: http://pe-harta.ro/alba/

Among the anthropic tourism potential of the county, a big tourist attraction can be mentioned:

- ruins of cities and archaeological remains - Căpâlna fortress dacian ruins, included in UNESCO World Heritage along with 5 other dacian fortresses in Orastie Mountains, the Sebeş fortress ruins, medieval ruins from Colţeşti, the ruins of Mikes Castle from Cisteiu of Mures, Vinţu Martinuzzi

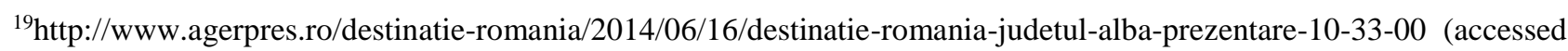
on 08.05 .2015$)$
} 
Castle ruins from Vințu de Jos, Tărtăria tablets considered to be the most important cultural ${ }^{20}$ historical vestiges of Romania;

- fortresses and castles-the german peasant fortress from Câlnic, included on UNESCO heritage site; the Vauban bastion fortress of Alba Iulia (built between 1715-1738 by the Austrian Emperor Carol VI, the work of thousands of romanian serfs) Aiud Fortress, Bethlen-Haller Castle from Cetatea de Baltă, Kemeny Castle from Sâncrai, Teleki Castle from Uioara de sus, Boteşti Castle, or the Kemeny Castle from the Galda de Jos;

- objectives and events of cultural, historical and artistic interest as museums - the National Union Museum, Union Hall, People's Reunification Cathedral, the St. Michael Roman Catholic Cathedral and Batthyaneum Library in Alba Iulia, history museums from Aiud, the Greco-Catholic Cathedral of Blaj, the Natural Science Museum from Aiud, which has the venerable age of 200 years; The Roşia Montană Mining Museum; the 25 ethnographic museums and exhibitions in the territory of the county;

- the memorial houses of personalities (poet and philosopher Lucian Blaga, Lancrăm, leader of the 1848 Revolution - Avram Iancu, Avram Iancu village, the uprisingpeasant leader Horea, Fericet village, the young pianist Carl Filtsch and naturalist Franz Binder, Sebes);

- historical and cultural events (1546 - Alba Iulia became the capital of the autonomous Principality of Transylvania, 1600 -in Alba Iulia it occurs the first unification of the three romanian principalities: Transylvania, Moldavia and Romanian Country, under the great prince Michael the Brave, 1784 -the great uprising of Horia, Cloşca and Crişan, XVII - XVIII century - a very special cultural period: 1648 -The New Testament from Bălgrad, The Transylvanian School with Samuel Micu, Gheorghe Şincai and Petru Maior; cultural centers of the feudal era at Alba Iulia and Blaj with the revolution between 1848-1849 with The Great Assembly on Liberty field at Blaj, the great work of the great tribune of "Moţilor" country Avram Iancu;, "1 December 1918" when the Great National Assembly from Alba Iulia was held and it confirms the unanimous vote in 1228 of representatives of the population from Transylvania, that represents the union with Romania) ${ }^{21}$; festivals (Dacian Fortresses Festival, an itinerant festival which has reached its ninth edition, the International Festival of Ethnographic Film, Zlatna), sporting events (athletics competition "Alba Iulia City Race"), competitions ("Walking with the history book" "Culture for culture"), fair s( The Rural Tourism Fair in Albac);

- elements of ethnography and folklore-the specific folk architecture from "Ţara Moţilor" ( the construction of wooden churches from Arieșeni, Gârda de Sus and Vidra) or Trascău Depression (Rimetea village which in 1999 was awarded the "Europa Nostra" Prize from the European Commission for the conservation of the cultural heritage, represented by white houses with green windows being unchanged for hundreds of years, attracting many tourists and in 2013 was ranked among the top five most beautiful villages in Romania, also being on UNESCO's World Heritage ${ }^{22}$ pending list), the traditional costumes specific for the 6 ethnographic regions ${ }^{23}$ of the county, folk music and dance, creation and popular technique, customs and traditions ("Înmormântarea Fârşangului " Rimetea; "Statu' la vase” Şugag; "Harvest Ingathering "Ampoiţa), festivals and fairs (Girl's Fair from" Muntele Găina"), events and religious beliefs ("The exit in the heaven "Ampoiţa), gastronomy (" Wine Road "in Alba County);

- present technical and economic achievements - the big number of lakes from the Sebeş of which the largest is Oaşa Lake with an area of 447 ha and 131 million $\mathrm{m} 3$ of water; the craft

\footnotetext{
${ }^{20}$ Some experts consider the first form of writing in the world, as it is written on the monument - the Tablets of Tărtăria

${ }^{21} \mathrm{http} / / / \mathrm{www} . \mathrm{cjalba} \cdot \mathrm{ro} / \mathrm{istoric/}$

${ }^{22}$ http://whc.unesco.org/en/tentativelists/5683/

${ }^{23}$ Alba County Council and the National Museum of Alba Iulia, The traditional romanian clothes from the Folk Heritage ethnographic exhibition in Alba County, in 2012
} 
workshops places from Bucerdea Vinoasă, Biia, Săsciori, Şugag, Vidra, Arieşeni, Horea, Avram Iancu and Horea, where young people continue the traditions ${ }^{24}$;

- human settlements: urban centers as Alba Iulia, Sebeş, Blaj, etc. or certain rural places cosidered tourist villages even if not declared so (Rimetea, Albac, Şugag).

According to a survey ${ }^{25}$ conducted by the Unirea newspaper in 2014 , the most attractive tourism resources in Alba County are: The Alba Carolina Citadel, is the largest fortress from Romania and one of the most imposing in the South -East Europe, located right inside the city , "Scărişoara glacier" cave or the giant ice cave, first cave declared a natural monument in 1938 in Romania and which houses the country's largest glacier first size glacier in the country and second in the world, with an age of 4,000 years, Detunatele ("Goală şi Flocoasă") which is a geological reservation (1936) unique in the country because of the peaks - 1,238 m maximum altitude, with form of hexagonal basalt columns, like some giant church organ, which is formed and extending on an area of 24 hectares, Rapa Rosie, also called the small canyon of Romania, spectacular geological and flora reservation, the only of its kind in the country on the basis of which the marshy land of the riverbed Secas, was discovered the skeleton of a carnivorous fossilized dinosaur - "Velociraptor", Câlnic Fortress, a Romanesque building with an impressive history of over 700 years, part of the UNESCO World Heritage, Rimetea village which has a unique architecture in the world of nineteenth century - whitewashed houses with green windows, unchanged for hundreds of years with outstanding landscapes "decorated" with rocks and the first rural town that was awarded by the European Commission in 1999, with the "Europa Nostra" Prize for the conservation of its cultural and architectural heritage, The Aiud Fortress is one of the few medieval ensembles, kept almost intact, in the same form as the people in the Middle Ages saw it, The "Huda lui Papară" cave which is the longest cave in Trascău Mountains, the most difficult and uneven, with the largest room, with the highest gallery, with the longest water course and the highest underground waterfall in the country, and not least, with the largest colonies of bats in Europe.

All these components of the tourism potential that Alba County has, show favorable features for the development of touristic activities that respond to extremely varied tourism needs of the people.

The importance and the role of tourism in the economic and social life of Alba County The main actors on any tourism market, including Alba County are classified into the following categories:

- tourism providers who are offering tourists or businesses in certain situations, the resident population, accommodation services, catering, transport and transfer of tourists to and from tourist destinations, leisure services, entertainment, spa treatment etc.

- intermediaries that provide the tourist services for the tourists or for the tour operators or wholesalers form the tourism market (those who develop tourist packages) and the travel agencies that sell travel products directly to the interested persons or tourists

- real tourism demand represented by people who at one time practice tourism or potential given by those who wish to practice, but at some point do not do it for a variety of reasons (financial, lack of free time).

- The State through: the National Tourism Authority, Alba County Council, the Institution of the Regional Governor of Alba County, urban and rural municipalities who benefit from taxes paid by tourism operators

\footnotetext{
${ }^{24} \mathrm{http}: / /$ proalba.ro/mestesugurile-traditionale-din-judetul-alba-din-nou-prezente-peste-hotare/\#sthash.aQx o4kZH.dpuf

${ }^{25} \mathrm{http}$ ///ziarulunirea.ro/sondajcele-mai-frumoase-atractii-turistice-din-alba-care-credeti-ca-sunt-locurile-care-trebuieneaparat-vizitate-de-turisti-in-judetul-din-inima-transilvaniei-270605/
} 
- any other entity (institution, NGO) that has the power to stimulate and promote tourism activities and

- local people.

Any tourist destinationexists and develops through the joint action of all those mentioned above.

Within the context of the economic impact of tourism in Romania in $2014^{26}$ is being quantified as it follows: $2.5 \%$ of the total employed people from our country, are working in this sector (205,000 direct jobs in tourism and 467,500 indirect tourism jobs 5.5\%), the returns from tourism flows linked with exports are 7.3 billion Ron (2.5\% of total exports), more than 8 million foreign tourist arrivals, investments worth 10.8 billion Ron $(7.3 \%$ of total investments in the economy), in Alba County it can be said that the tourism sector occupies a modest place.

For 2025, the importance of tourism activity in Romania will be reflected in the evolution of these indicators as it follows: the contribution of tourism to national GDP will grow at a rate of $3.8 \%$ per year reaching $5.1 \%$ in 2025 , the number of people directly employed in tourism will be 207,000 , revenues from international tourism will double to 14.4 billion lei, the investment will increase to $7.6 \%$.

Specifically, being analyzed in relation to the overall economy of Alba county, the tourism acts as a stimulating factor for the entire economic system, as it follows:

- by developing this type of business is getting a production increase; if the national direct contribution of tourism to GDP was $1.6 \%$ (10.9 billion USD) in 2014, and the total (indirect) was $4.8 \%{ }^{27}$ and it was generated by the economic activity of the hotels, tourism agencies, airlines and other tourism transport companies, restaurants and leisure facilities, entertainment for tourists, at the Centre Region level and also at Alba County's level the tourism's economic role is maintained at a very low level, recording in the recent years a decreasing trend in the regional GDP. The tourism share in total regional gross domestic product was $2.1 \%$ in $2008,{ }^{28}$ while in 2011 , taking in acount that there is no longer distinct highlighted only the "Hotels and restaurants" sector but taken together with other economic activities such as "wholesale and retail trade; repair of motor vehicles and motorcycles, transportation and storage ", reached $10.65 \%$ but this percentage is not relevant in the above plea.

- the driving effects manifested, of production stimulation in other areas or even the emergence of new sectors, the result of his character interference and synthesis branch, meaning that the activity of some branches is largely determined by the needs of tourists, such as agriculture, food industry, construction, transport, cultural services and the emergence of specific branches (activities): leisure industry, cable transport, travel, production of handicrafts, souvenirs or commercialization of sports, local and regional tourist transport, etc. For example, at the Centre Region's level the entertainment, cultural and recreation activities contributes with $2.8 \%$ of total ${ }^{29}$ regional GDP, indicating an upward trend in recent years.

The tourism activity from Alba's County, it represents a way of superior capitalization of all resources categories ${ }^{30}$, and in particular the natural ones (the beauty of the landscape, the climatic conditions from the Apuseni Mountains and Sebeş valley), cultural and artistic events that attract more and more visitors and tourists, historical relics, folk tradition find their best value in some cases even only through tourism. How can it be exploited the karst area of the Apuseni

\footnotetext{
${ }^{26}$ World Travel \& Tourism Council, Trave\& Tourism Economic Impact 1 2015, Romania, available on http://www.wttc.org/-/media/files/reports/economic\%20impact\%20research/countries\%202015/ romania2015.pdf

${ }^{27}$ World Travel \& Tourism Council, Trave\& Tourism Economic Impact 1 2015, Romania, available on http://www.wttc.org/-/media/files/reports/economic\%20impact\%20research/countries\%202015/ romania2015.pdf

${ }^{28} \mathrm{http}: / /$ www.alba.insse.ro/cmsalba/files/stat_reg/produsul\%20intern\%20brut\%20regional4.htm

${ }^{29} \mathrm{http} / / / \mathrm{www}$. alba.insse.ro/cmsalba/files/stat_reg/produsul\%20intern\%20brut\%20regional4.htm

${ }^{30}$ Minciu, R., Tourism Economy, Third Edition, Uranus Publishing House, Bucharest, 2004
} 
Mountains, the beautiful landscape of the "Stone Country", the Sebeş Valley or the Trascău Basin, the specific ethnography and folklore of Alba county, other than by tourism?

Furthermore, tourism is capable of causing mutations in the territorial development and in this regard it is considered a lever to alleviate the imbalances seen between counties taken at a regional scale. The investments in Alba County were concentrated in its center - Alba Iulia and Sebeş municipalities and the communes Galda de Jos, Sântimbru, Ciugud and Vinţu de Jos - but also in Blaj and Cugir cities, by passing the area most affected by reorganization - the Apuseni mountains $^{31}$. Given that, the lowest economic development held by the Apuseni Mountains sparsely populated areas in the county, and there were mono-industrial areas with declining economic activity (Zlatna, Baia de Arieş, Abrud), the tourism, through its forms (adventure tourism, rural tourism) may be the only way to exploit the resources available to them. The territorial distribution of the 57245 active companies of the Central Region (2013) ${ }^{32}$, shows a concentration in the counties of Brasov, Mureş, Sibiu and a weak presence in Alba County (7,321 or 12.78\%) of which 3,779 operate in regional tourism respectively 489 county tourism. The turnover of the active entities in the "Hotels and restaurants" sector in Alba County was 120 million ron ${ }^{33}$ in 2012, representing only $0.9 \%$ of all economic activity in the county.

Tourism development at the county level brings a positive influence on the use of work force, as it follows:

- the tourism creats new jobs, having a major contributor to attract surplus labor from other sectors and thus alleviate unemployment. In Alba County, in 2012, there were 77,467 ${ }^{34}$ employees (13.6\% of the total employment in the Central Region and 1.7\% nationally) from which 1,376 people working in tourism, specifically in the "Hotels and restaurants" sector, representing $7.7 \%$ of the average number of employees working in tourism in the Central Region and $1.7 \%$ from the total employees number from the the county's economy. If we analyze the active population from the same sector "Hotels and Restaurants", during $2013^{35}$ the indicator level was 2.5 thousand people at the county level, which represents $9.9 \%$ of the workforce in the Central Region and 1.6 nationally . Regarding the wage levels in tourism, the average monthly net salary that is earned by an employee from the "Hotels and restaurants" sector is the lowest at the national level, $888 \mathrm{lei}^{36}$, while the average monthly salary in Romania in 2008 it was 1.535 lei. For the employees working in the "Hotels and restaurants" sector in Alba county, in the year $2012^{37}$ there was a monthly net average earning below the national average (1276 lei) and regional (809 lei) of 681 lei. So, because of poor payment conditions, we certainly cannot talk about attracting labor force from other economic sectors towards the tourism sector.

- tourism contributes to the increase of the level of education and workforce training. In the tourism sector, as in the whole service sector, the role of the human factor is extremely important because without well-trained employees from the professional point of view, there cannot be provided quality travel services. The tourism worker must be a person with high skill levels, with a broad horizon of knowledge, with a great knowledge of international languages, a good psychologist and to be able to promote the touristic programs and services. According to studies conducted in the main european touristic countries with the European, the structure regarding the qualification of people employed in tourism is as it follows: approximately $40 \%$ of all tourism personnel is unqualified, $42 \%$ have general secondary education, $8 \%$ specialized studies and only

\footnotetext{
31 The Agency for Regional Development, The smart specialization strategy of the Central Region, Regional Diagnostics 2014

${ }^{32}$ http://statistici.insse.ro/shop/

${ }^{33} \mathrm{http}: / /$ www.alba.insse.ro/cmsalba/files/statistici judetene/Cifra\%20de\%20afaceri\%20a\%20unităţilor \%20lo.htm

${ }^{34} \mathrm{http}: / /$ www.alba.insse.ro/cmsalba/files/stat reg/Numărul\%20mediu\%20al\%20salariaţilor\% 20pe\%20activitati.htm

${ }^{35} \mathrm{http}: / /$ statistici.insse.ro/shop/index.jsp?page=tempo3\&lang=ro\&ind=FOM103D

${ }^{36}$ The latest available statistics from NIS refer to 2008

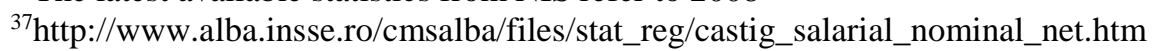


$10 \%$ higher education. Currently, Romanian tourism and both the county tourism is facing lowskilled work force issue. Following the economic reorganization, which had as a negative effect the huge increase in the number of unemployed skilled labor in certain areas (ie. mining, metallurgical, chemical, etc.) and it must adapt to new economic activities (ex. tourism, services, etc.).Therefore, to meet the requirements of foreign employers and foreign investors in Romania, both in general and in Alba county, mainly, who are demanding, because of their tens of millions of euros as investment, claim a certain level of professional competence and the persons employed in tourism activity or those who plan to become employed in tourism must have the required knowledge.

In the present time, we can speak of a period of continuous training and development of human resources, in the Alba county's tourism, only through European funds (especially PSDRU projects), employees from travel agencies can follow various training courses for both basic specifc occupations and tourism management positions. In 2014, the OIRPOSDRU of the Central Region managed the implementation of 82 projects and strategic grants, with a total value of 397,373,167 lei of which, certainly, some beneficiaries were employees of Alba county's tourist sector or persons seeking employment in tourism.

Tourism has beyond economic consequences, a profound social and human significance ${ }^{39}$, through:

- its content (the body's natural recovery capacity, mediates the activity of education, raises the level of education, culture and civilization of the people), tourism has a great importance in meeting people's material and spiritual needs, influencing the size and structure of consumption

- from the social piont of view, tourism is seen an an important way of using the leisure time. If in the $80 \mathrm{~s}$ about half of the county population from Alba practiced tourism, today the tourist consumption fell to about $15 \%$, and fits into the national trend.

Also at the socio-cultural and political level, tourism acts towards strengthening and diversifying of relations between the nations. As long as tourists are free to travel almost everywhere in the world, certainly we can say that tourism has a beneficial role in human relations.

The valuation level of the existing tourism potential in Alba County can be highlighted through the levels and the dynamic evolution of the main indicators of infrastructure and tourist traffic. So at county's level, the tourism infrastructure can be characterized by the following indicators: number of tourists accomodation places (see table no. 1), receiving capacity (see fig no. 2 ), indicators of use of the net capacity in operation.

Table no. 1

The evolution of the number of receiving accommodation units of tourists in Alba County between 2010-2014

\begin{tabular}{|c|c|c|c|c|c|}
\hline \multirow{2}{*}{ Type of tourist accommodation unit } & \multicolumn{5}{|c|}{ Number of units } \\
\cline { 2 - 6 } & 2010 & 2011 & 2012 & 2013 & 2014 \\
\hline Hotels & 10 & 13 & 12 & 15 & 15 \\
\hline Hostels & 2 & 2 & 2 & 1 & 1 \\
\hline Motels & 1 & 3 & 6 & 7 & 7 \\
\hline Tourist villas & 3 & 3 & 3 & 3 & 6 \\
\hline Tourist cottages & 6 & 5 & 5 & 7 & 7 \\
\hline Campings & - & 1 & 1 & 1 & 1 \\
\hline School and preschool camps & 3 & 3 & 3 & 3 & 3 \\
\hline Urban boarding house & 6 & 17 & 20 & 22 & 25 \\
\hline Rural bording houses and agrotourist boarding houses & 36 & 53 & 61 & 62 & 75 \\
\hline TOTAL & $\mathbf{6 7}$ & $\mathbf{1 0 0}$ & $\mathbf{1 1 3}$ & $\mathbf{1 2 1}$ & $\mathbf{1 4 0}$ \\
\hline
\end{tabular}

Source: author's contribution based on statistical data retrieved from INSSE, http://statistici.insse.ro/shop/

\footnotetext{
${ }^{38} \mathrm{http} / / /$ www.oirposdrucentru.ro/wp-content/uploads/2015/02/Raport-activitate-2014.pdf

${ }^{39}$ Minciu R., Tourism economy, the revised third edition, Uranus Publishing House, Bucharest, 2004.
} 
As it can be seen, the number of tourist units has doubled in the period under review, based on the spectacular growth in the number of both tourist and agro guesthouses. This is explained by the fact that, in Alba County, the demand for specific rural tourism and agrotourism it manifested and is manifesting more intensely and, on the other hand, the investments in such units have been supported by European financing funds.

Analyzing the information available on the official website of the National Tourism Authority (NTA) ${ }^{40}$, there is an inconsistency between the two data sources in terms of the number of tourism units that currently exists in the county, meaning that at the central body are licensed to operate 237 structures with functions of tourist accommodation with a total capacity of 5641 beds (1.8\% of the total accommodation capacity of Romania and $14.5 \%$ in the Central Region), ranging from 1 -5 star/daisies, as degree of comfort, most of which are rural and urban boarding, followed by hotels, villas, apartments and rooms for rent, cabins and campgrounds and at the National Institute of Statistics are recorded only 140 units.

As territorial distribution, most are located on the upper valley of Aries, in Aries and Albac resorts, in Garda de Sus village, Alba Iulia city, Rimetea village, Sebeş Valley and in the rural areas of our county, aspect that encoureges the development of specific forms of tourism such as rural tourism and agritourism, ecotourism, hiking and outdoors.

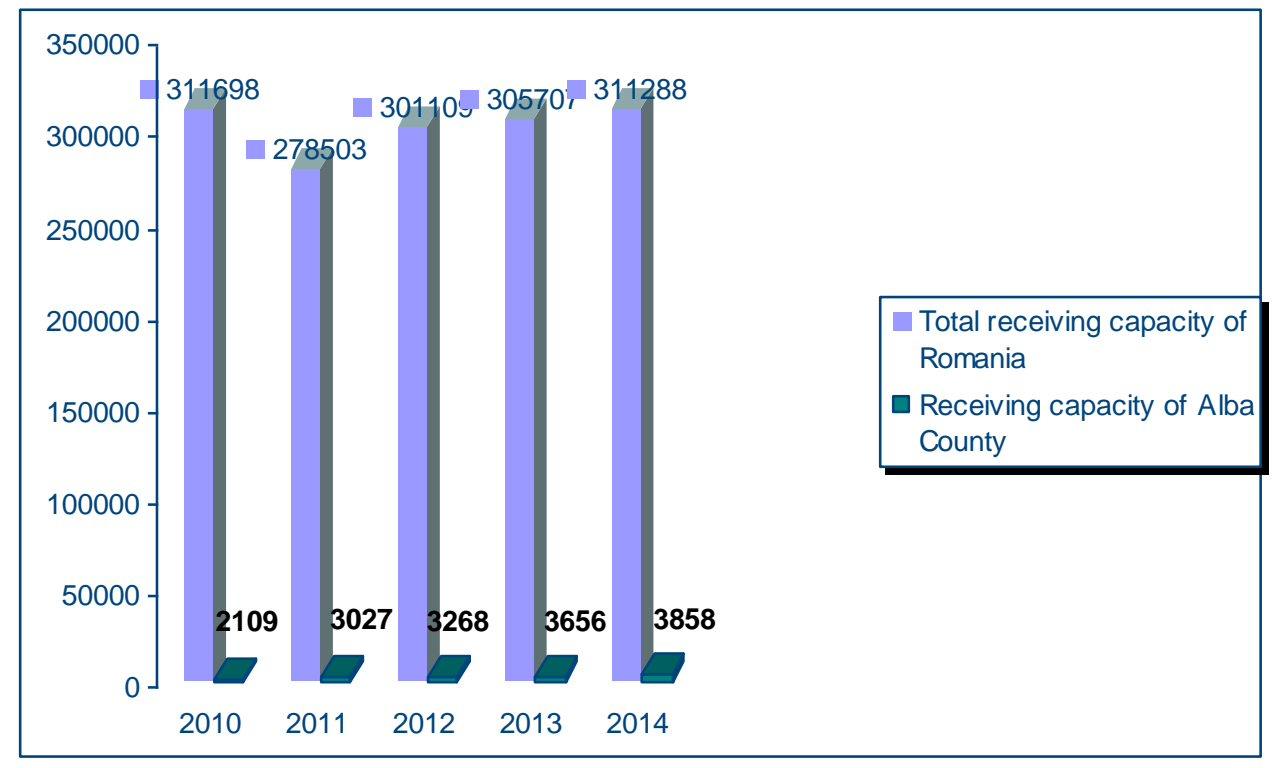

Fig. no. 2 The accommodation capacity in Alba County

Source: author's contribution based on statistical data from INSSE

Although the economic and financial crisis has left its mark on Alba County, the accommodation capacity has shown an upward trend in the 2010-2014 period, from 2109 beds in 2010 until 3858 in 2014, almost double a very short time.

Alba County's tourism infrastructure is represented, in addition to accommodation establishment's network, and public alimentation units' network, travel agencies, tourist information centers and special sky facilities. Thus, in Alba operate:

- 99 tourist accommodation structures with functions of alimentation, classical type restaurants or boarding house restaurants, cocktail bar, cafe bar, wine cellar or fast food, ranging from 1 to 5 stars, located in the county capital or in urban and rural areas with functions of tourism;

\footnotetext{
${ }^{40} \mathrm{http}: / /$ turism.gov.ro/informatii-publice/(accessed on 06.19.2015)
} 
- 47 travel agencies spread throughout the Alba, that unfortunately, do not provides tourist products in our county, but tourists are sending tourists to various tourist destinations located outside Alba county and country. In 2014, the national number of tourists participating in tourist activities organized by travel agencies was as it follows: 219,513 visitors attended the incoming actions, 1,027,464 tourists participated in activities at outgoing and just 502.101 practiced domestic tourism;

- some tourist information centers, appeared on the map of the county as a result of EU funded initiatives but, they do not work as it should (with employees and promotional materials) whereas through the projects that were set up, there were not eligible, only the expenses with investments in material resources as the buildings;

- 10 ski runs totaling 10,110 $\mathrm{m}$ in length, with varying difficulty as (the majority average) $80 \%$ located in the ski area Şureanu and only $20 \%$ in Vârtop-Arieșeni area.

From a simple analysis of the tourist infrastructure that Alba County currently has, it seems that there is a satisfactory number of tourist units as typology and degree of comfort, but in terms of their territorial distribution and services it needs continuous development and diversification to meet tourists needs that are increasingly complex and sophisticated. This can be achieved through investment in leisure centers, multipurpose sports fields, amusement parks or even treatment centers, given the fact that Alba has curative factors that can be capitalized through spa tourism.

In terms of tourist movement, the main indicators that must be considered are the number of registered tourists at the county level, the number of overnight stays, length of stay, etc.

Despite having a highly varied and attractive tourism potential, and also a relatively good promotion, Alba county is situated on the last positions regarding the number of tourists, in the Centre Region. From the almost 2 million tourists who visited the Central Region in 2014, nearly 1.6 million chose Braşov. Mureş County it follows with 408,843 people, Sibiu with 354,655 people, Harghita with 122,752 tourists, Alba County with 107,271 people and Covasna with 88,383 visitors. From the total number of tourists visiting Alba, Alba Iulia city is mostly chosen as a tourist destination due to its special historical cultural heritage available and good promotion. Thus, if in 2007-2008 the number of tourists visiting Alba Iulia did not exceed 32,000, currently, the city attracts over $400,000^{41}$ visitors per year. Moreover, there is a further growth trend regarding the number of visitors to the Grand Union City.
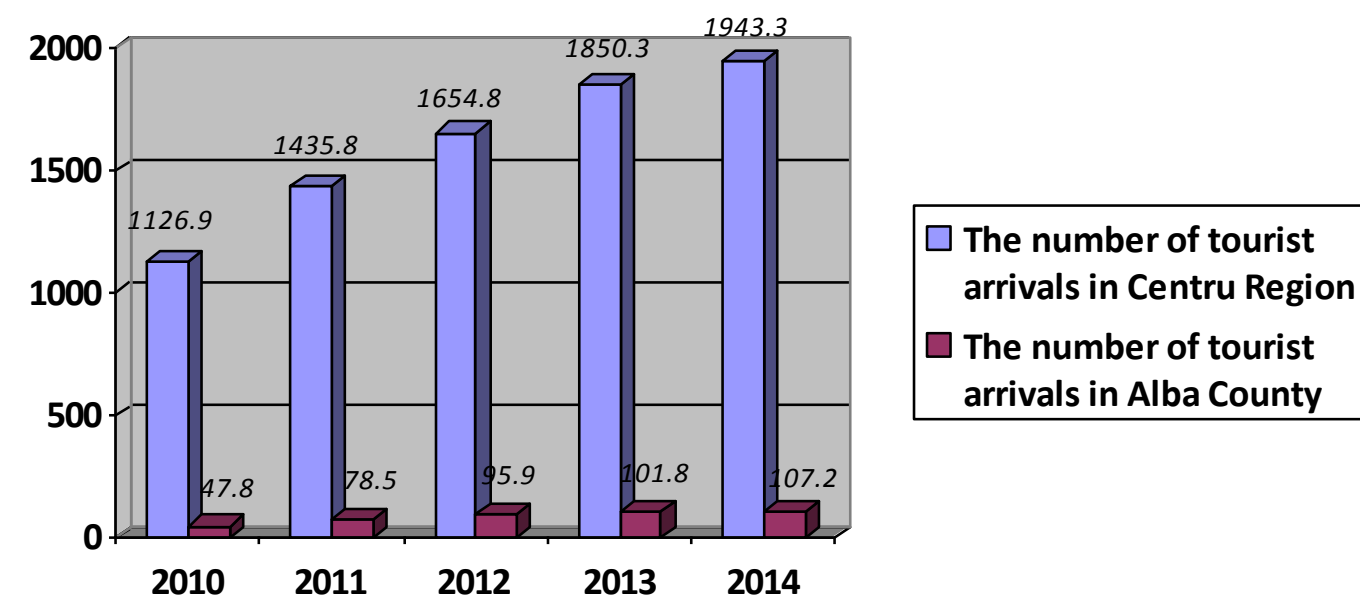

Fig. no. 3

The evolution of the tourist arrivals in Alba County between 2010-2014

Source: author's contribution based on statistical data from INSSE

\footnotetext{
${ }^{41}$ Nicolaie Moldovan, Alba Iulia's city manager
} 
The number of tourist arrivals at the county's level is of course, closely linked to the number and capacity of the tourism facilities and showed the same trend of growth in the analyzed period.

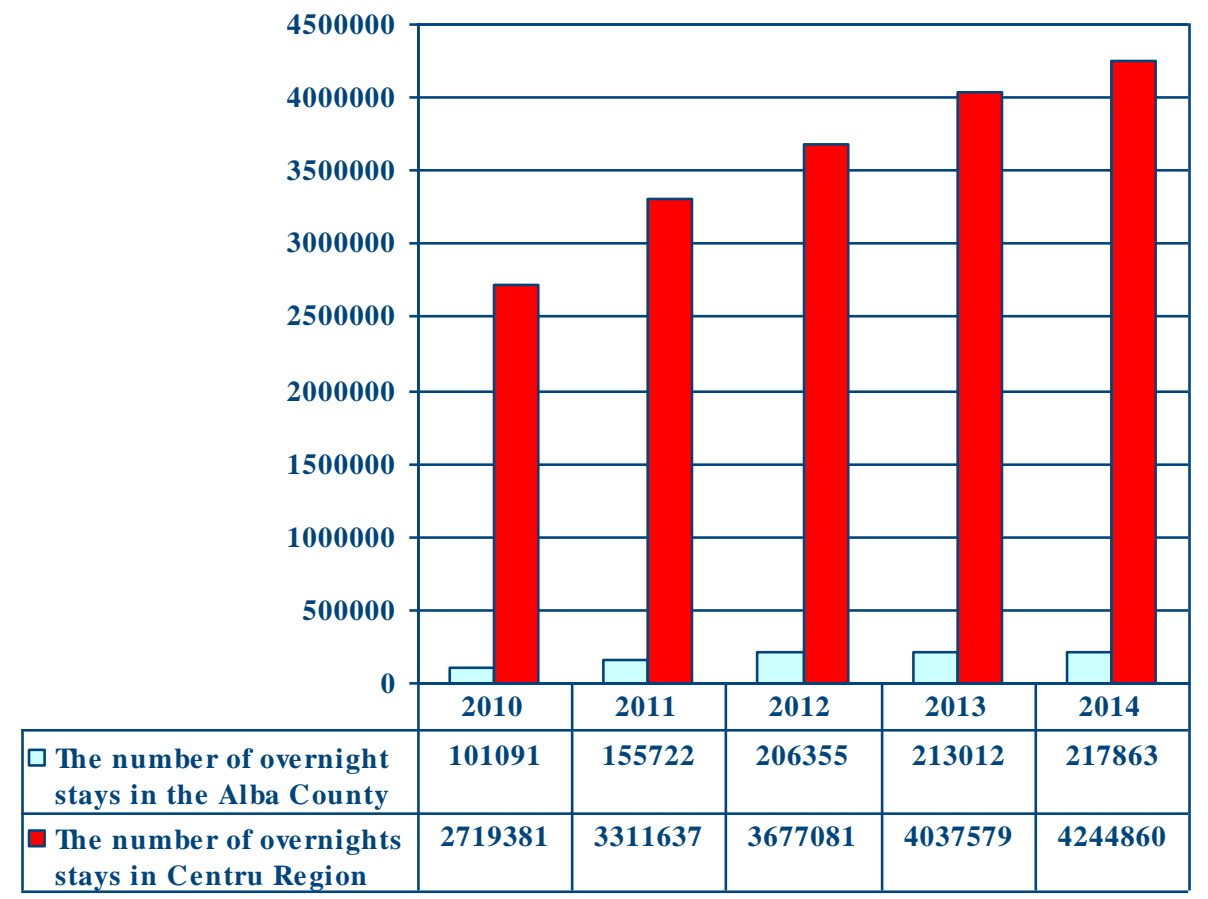

Fig. no. 4

The evolution of the indicator - the number of overnight stays in the county of Alba in 2010-2014

Source: author's contribution based on statistical data from INSSE

Only in the case of Alba Iulia, the annual number of overnight stays increased in 2013 to almost 82,000 compared to 72,000 in 2012 . It is possible that in the coming years to reach the level of 90,000 overnight stays/year.

Regarding the average length of stay, the amount recorded for tourists visiting our region stands at 2.4 days as national value. For example, most people who spend the night in the accommodation units in Alba Iulia are tourists in transit or choosing city break products.

According to the Alba County's tourism market study, conducted by "1 December 1918" the university from Alba Iulia ${ }^{42}$, for Alba County Council, the tourists who choose Alba as a holiday destination can be described as persons ${ }^{43}$ :

- Who come from the county with the same name, from the neighbouring counties and from those located in central, southern and northern Romania or from other Central and Eastern Europe countries, and less from Western Europe countries;

- Who use personal sources of information (friends, colleagues, acquaintances, relatives) and the online environment (websites, blogs, social networks) to inform on the Alba County as a tourist destination; Alba County is not sufficiently promoted among tourists through the known promotional techniques (through travel agencies, advertising in media, online advertising, etc.) and does not have a contoured identity in terms of tourism brand;

- Who are relatively loyal to Alba as a tourist destination; most tourists have expressed their willingness to return to Alba County and to recommend it to others;

\footnotetext{
${ }^{42}$ Alba County Council, "1 December 1918" University of Alba Iulia - Department of Economics and Business Administration ,Ttourism market study in Alba County, in 2014

${ }^{43}$ Muntean A., Moisă C., The profile of the tourists who choose Alba county as a tourist destination, Annales Universitatis Apulensis Series Oeconomica, 16(2), 2014.
} 
- Who are attracted to the micro-regions of Alba Iulia, Rimetea, Arieşeni-Cîmpeni, Frumoasei Valley and to sights such as the Alba Carolina Fortress (Alba Iulia), "Scarisoara Glacier" Cave, Patru's Peak in Şureanu Mountains, the locality of Rimetea, Râmeţ Gorge; in the city of Alba Iulia, the most visited attractions are the Alba Carolina Citadel, the Roman Catholic Cathedral and the National Museum; the "pride of being Romanian" was experienced by most tourists who visited the Union Museum and the Union Hall;

- Who spend an average stay of 4.02 days and an average amount of 449 Ron;

- Who choose to practice a tourism of rest, relaxation and recreation, but also mountain, rural and agro-tourism, as well as other forms of tourism such as visiting relatives and friends, religion, pilgrimages, and so forth;

- Whose main reasons for choosing a destination are the natural environment, the desire for knowledge, the hospitality of tourism service providers and the cultural- historical potential, which indicates that they are nature lovers, interested in knowing new things about the environment or about the culture of different areas and likely to take part in unique experiences;

- Who choose to spend their stay sightseeing, making excursions in the surroundings or hiking;

- Who travel with their family or with a group of friends and use their personal car as the main means of transport;

- Who had chosen their destination together with all the group members, wives having more influence than husbands; agencies;

- Who prefer to book in advance directly at the tourism units and only few do it through

- Who use location and the quality of the services offered as main criteria for choosing the accommodation unit;

- Who appreciate the quality of the tourism services offered as an important and very important aspect of providing the service;

- Whose opinion on the various attributes of the accommodation units' design is that they provide a pleasant, familial environment, and service is appropriate;

- Who had a favourable opinion regarding the staff's kindness (in accommodation and catering units) and the leisure opportunities;

- Who consider it very important the existence of tourist information points in different tourist regions of the county.

- Who consider that cultural events in the county, important for attracting significant numbers of tourists are the "Dacian Fortresses Festival" and the "Dilema Veche Festival"

- Young people aged up to 35 years;

- Educated over the average, usually with high education;

- Both women and men - $50 \%$ women and $50 \%$ men;

- With average incomes, taking into account that Alba County is not an expensive tourist destination.

The wider context of economic and social development of Alba County includes various business opportunities, including tourism. Thus, it is about domestic and international events organized in the county or the Centre Region aiming the development of Romanian-foreign partnerships. The first steps of this type were made in 2007 when German investors have established partnerships in renewable energy, from 2010 a German corporation conducts business in the food industry, and more recently (2014) occurred:

- "International Conference on European resources for a successful economic partnership" organized by "ADR Centru" which aimed to develop bilateral Romanian-German business in hospitality area - hotels and prospecting Alba County tourism potential, with direct influence on the expansion of tourism through local and regional resources(tourism resources, gastronomy wine, work force, logistics and transportation, food industry etc.). 
- Best practice exchanges for tourism business development and workforce qualification, specifically based on establishing partnerships to access European funds for romanian employees specialization, so they can occupy qualified jobs in Europe. The county tourism SMEs can access business grants through POR 2014-2020, step that could be facilitated by relevant organizations (tourism associations from different European countries).

\section{Conclusions}

Even if the main branches of Alba County's economy are dominated by mining, energy, machine building, chemical, building materials, wood processing and food service sector and tourism also, have a fairly significant contribution to the formation of the county's gross domestic product, registering a significant development in recent years. Tourism, although with some progress recorded in some segments, such as rural tourism and agritourism, still fails to capitalize on the significant tourism potential of the county. Regionally, tourism is one of the most dynamic economic sectors from the Central Region, which however has not reached the required development of the extremely rich tourist potential of the region. In 2014, the Centre Region has succeeded in attracting 1,953,000 millions tourists that used the accommodation units (23.06\% of arrivals at national level ${ }^{44}$ ), the first region of the country as a tourist destination.

Given that one of the six strategic areas of development in Central Region is "The development of tourism, cultural and recreational support activities ${ }^{45 "}$, it can be said that even in Alba County, tourism activity will become an important economic sector in the near future especially given that there will be sufficient EU funding sources or other investments to support the investments and the training of human resources in the field.

Tourism development in Alba County will also involve other areas of economic and social development (transport infrastructure, handicrafts industries, food industry, various services) thereby generating a multiplier effect in the local economy.

Alba County has special tourist valences, partially capitalized, characterized by beauty and diverse landscape of the whole territory as a result of hydrography, climate and vegetation, plus many elements of material culture of anthropogenic origin, ethnography and folk art items. The few villages, of which representative is Rimetea, that managed to capitalize its own natural and anthropogenic resources in tourism, can role models for many other towns in the county and, why not, in the Central Region and in our country that have a real tourism potential.

In conclusion, we can say that Alba County tourism market, represented by infrastructure and tourist traffic is relatively well developed as the number of units, territorial spread, tourist movement and has a huge development potential if we think about certain tourism products or forms of tourism (cultural tourism, business tourism, adventure tourism) that can be developed. By knowing the expectations of the potential clients, there will be created tourism products tailored to the needs and wishes of individual tourists or tourist groups interested Alba as a tourist destination. Thereby Alba has all the required resources to become a major tourist destination on both domestic and international market.

\section{Bibliography}

1. Alexa O., The castles Map from Alba: luxury residences and ruins. See what remains of monuments of old architecture, available athttp://alba24.ro/resedinte-de-lux-spitale-sali-deconferinte-de-expozitii-sau-ruine-vezi-cum-se-prezinta-castelele-din-judetul-alba215646.html

2. Aziri B., Nedelea Al., Business strategies in tourism, ECOFORUM Revue, Volume 2, Issue 1(2), 2013.

\footnotetext{
${ }^{44} \mathrm{http}: / /$ statistici.insse.ro/shop/index.jsp?page=tempo3\&lang=ro\&ind=TUR104B

${ }^{45} \mathrm{http}$ ///eufinantare.info/Documente/STRATEGIE-CENTRU-2014-2020_Iulie_2013.pdf
} 
3. Borza A. (eds.), Tourist capitalization of tangible and intangible heritage of Alba County, ALTIP Publishing House, Alba Iulia, 2014.

4. Măhăra Gh., Reservations and natural monuments in Alba County, Terra, 2: 23-27, 1982.

5. Minciu R., Tourism Economy, Third Edition revised, Publisher Uranus, Bucharest, 2004.

6. Muntean A., Moisă C., The profile of the tourists who choose Alba county as a tourist destination, Annales Universitatis Apulensis Series Oeconomica, 16(2), 2014.

7. ***The Agency for Regional Development, Smart specialization strategy Central Region, Regional Diagnostics 2014.

8. ***ADR Centre, Issues on tourism development in the Central Region, (2011)

9. ***ADR Centre, Central Region Development Strategy 2014-2020, available at http://eufinantare.info/Documente/STRATEGIE-CENTRU-2014-2020_Iulie_2013.pdf

10. ***Alba County Council, 2012, Alba County. Travel Guide, Vega Prod Publishing House, Buzău.

11. ***Alba County Council, "1 Decembrie 1918" University of Alba Iulia, Department of Economics and Business Administration, Tourism market study in Alba County, in 2014

12. National Institute of Statistics (www.insse.ro) 